\title{
GAMBARAN TINGKAT STRES MASYARAKAT TERHADAP PENYAKIT COVID-19
}

Connie M. Sianiper, Hotmaria Br Gurning

Program Studi D3 Keperawatan STIKes Santa Elisabeth Medan, Indonesia cinnie_ms@yahoo.com, Hotmagurning233@gmail.com

\begin{tabular}{ll}
\hline & \\
\hline Received: & 02-02-2022 \\
Accepted: & 02-02-2022 \\
Published: & 20-02-2022 \\
Keywords: & stress level; \\
& public; covid-19
\end{tabular}

\begin{abstract}
Stress is a state of tension, when a person faces a problem or challenge and cannot find a way out, so it could be because when he starts looking for solutions, many other thoughts are disturbing, here there is an imbalance between guidance and the ability to overcome them. The purpose of this study was to describe the level of public stress on the Covid-19 disease in Simangalam Village, Labuhan Batu Utara District, Kualuh Selatan Regency in 2021. This study used a descriptive research design. The population in this study was the Simangalam Village community, Labuhan Batu Utara District and the researchers examined as many as 51 respondents. The sampling technique in this study used a proportional sampling technique. The measurement instrument in this study used a questionnaire. Based on the results of the study, it was concluded that the community had the highest level of stress related to Covid-19 disease, with 26 respondents responding to mild stress (88.2\%) and the lowest responding to moderate stress level 6 (11.2\%).
\end{abstract}

\begin{tabular}{ll}
\hline & \\
\hline Kata & tingkat stress; \\
kunci: & $\begin{array}{l}\text { masyarakat; } \\
\text { covid-19 }\end{array}$
\end{tabular}

Abstrak

Stres adalah suatu keadaan ketegangan, ketika seseorang menghadapi suatu masalah atau tantangan dan tidak dapat menemukan jalan keluarnya, sehingga bisa jadi karena ketika ia mulai mencari solusi, banyak pikiran lain yang mengganggu, di sini terdapat ketidakseimbangan antara bimbingan dan kemampuan mengatasinya. Tujuan dari penelitian ini adalah untuk mengetahui gambaran tingkat stres masyarakat terhadap penyakit Covid-19 di Desa Simangalam Kecamatan Labuhan Batu Utara Kabupaten Kualuh Selatan tahun 2021. Penelitian ini menggunakan desain penelitian deskriptif. Populasi dalam penelitian ini adalah masyarakat Desa Simangalam Kecamatan Labuhan Batu Utara dan peneliti meneliti sebanyak 51 responden. Teknik pengambilan sampel dalam penelitian ini menggunakan teknik proporsional sampling. Instrumen pengukuran dalam penelitian ini menggunakan kuesioner. Berdasarkan hasil penelitian, disimpulkan bahwa masyarakat memiliki tingkat stres tertinggi terkait penyakit Covid-19, dengan responden merespon stres tingkat ringan 26 responden $(88,2 \%)$ dan terendah merespon stres tingkat sedang 6 responden $(11,2 \%)$. 


\section{PENDAHULUAN}

Covid-19 merupakan bencana non alam yang berdampak pada masyarakat luas. Kondisi ini memberikan dampak fisik dan psikis bagi setiap individu, terutama masyarakat yang mengalami isolasi atau karantina akibat Covid-19. Masyarakat harus tinggal di rumah sakit khusus karantina karena dianggap tidak bisa melakukan karantina mandiri di rumah dan berpotensi menyebarkan Covid-19. Hal ini dapat menimbulkan gangguan emosional berupa stres yang berlebihan akibat respon dari masyarakat sekitar (Handayani, Ayubi, \& Anshari, 2020).

Virus Corona 2019 atau Covid-19 merupakan virus Corona jenis baru, selain berdampak terhadap fisik juga dapat berdampak serius pada kesehatan mental seseorang (Huang \& Zhao, 2020), berbagai gangguan psikologis telah dilaporkan dan dipublikasikan selama mewabahnya Covid-19 di China, baik di tingkat individu, komunitas, nasional, maupun internasional. Pada tingkat individu, orang lebih cenderung mengalami ketakutan akan infeksi dan mengalami gejala yang parah atau sekarat, merasa tidak berdaya, dan membuat stereotip orang lain. Pandemi bahkan menyebabkan krisis psikologis seperti stres berkepanjangan, kecemasan, depresi dan trauma (Xiang et al., 2020).

Stres adalah reaksi normal terhadap situasi yang mengancam dan tidak terduga seperti pandemi virus corona. Kemungkinan reaksi terkait stres dalam menanggapi pandemi Coronavirus dapat mencakup perubahan konsentrasi, cepat marah, kecemasan, insomnia, penurunan produktivitas, dan konflik interpersonal, terutama berlaku untuk kelompok yang terkena dampak langsung. Terlepas dari ancaman yang ditimbulkan oleh virus itu sendiri, tidak diragukan lagi bahwa tindakan karantina yang diterapkan di banyak negara memiliki efek psikologis yang negatif, yang semakin meningkatkan gejala stres. Ketidakpastian umum, ancaman terhadap kesehatan individu dan tindakan karantina dapat memperburuk kondisi yang sudah ada sebelumnya seperti depresi, kecemasan, dan gangguan stres pascatrauma. Selain itu, risiko penularan penyakit dapat meningkatkan kontaminasi pada pasien dengan gangguan obsesif-kompulsif dan hipokondria, atau individu dengan ide paranoid. Meskipun tindakan karantina melindungi dari penyebaran virus corona, tindakan tersebut membutuhkan isolasi dan kesepian yang menciptakan stres psikososial utama dan dapat memperburuk penyakit mental (Vahia et al., 2020).

Perhimpunan Dokter Spesialis Penyakit Jiwa Indonesia (PDSKJI) melakukan survei kesehatan jiwa melalui pemeriksaan mandiri secara online. Pemeriksaan dilakukan terhadap 1.552 responden mengenai tiga masalah psikologis, yaitu kecemasan, depresi, dan trauma. Responden terbanyak adalah perempuan $(76,1 \%)$ dengan usia minimal 14 tahun dan maksimal 71 tahun. Responden terbanyak berasal dari Jawa Barat 23,4\%, DKI Jakarta 16,9\%, Jawa Tengah 15,5\%, dan Jawa Timur 12,8\% (PDSKJI, 2020). Hasil survei menunjukkan 63\% responden mengalami kecemasan dan 66\% responden mengalami depresi akibat pandemi Covid-19.

Selanjutnya sebanyak 80\% responden memiliki gejala stres pasca trauma. Psikologis karena mengalami atau menyaksikan peristiwa tidak menyenangkan terkait Covid-19. Gejala stres psikologis pasca trauma berat dialami oleh $46 \%$ responden, gejala stres psikologis pasca trauma sedang dialami oleh $33 \%$ responden, gejala stres psikologis pasca trauma ringan dialami oleh $2 \%$ responden, sedangkan $19 \%$ tidak ada. gejala. Gejala stres pasca trauma yang menonjol adalah stres perasaan jauh dan terpisah dari orang lain serta perasaan selalu waspada, hati-hati, dan waspada. Sementara itu, pemeriksaan lanjutan yang dilakukan terhadap 2.364 responden di 34 provinsi menyatakan, hasilnya tidak jauh berbeda dengan pemeriksaan sebelumnya. Sebanyak 69\% responden mengalami masalah psikologis. Sebanyak 68\% mengalami kecemasan, 67\% mengalami depresi, dan 77\% mengalami trauma psikologis. Sebanyak 49\% responden yang depresi malah memikirkan kematian (PDSKJI, 
2020). Data tersebut menggambarkan bahwa masalah kesehatan mental, seperti kecemasan, depresi, trauma akibat pandemi Covid-19 dirasakan masyarakat Indonesia saat ini.

Berdasarkan penelitian (Sulis, 2020) sebanyak 63\% responden mengalami kecemasan dan 66\% responden mengalami depresi akibat pandemi Covid-19. Gejala utama kecemasan adalah khawatir akan terjadi sesuatu yang buruk, terlalu khawatir, mudah tersinggung, dan sulit bersantai. Sedangkan gejala utama depresi yang muncul adalah gangguan tidur, kurang percaya diri, kelelahan, kurang energi, dan kehilangan minat. Selanjutnya, sebanyak 80\% responden memiliki gejala stres psikologis pasca trauma akibat mengalami dan menyaksikan kejadian yang tidak menyenangkan terkait Covid-19. Gejala stres psikologis pasca trauma berat dialami oleh $46 \%$ responden, gejala stres psikologis pasca trauma sedang dialami oleh $33 \%$ responden, gejala stres psikologis pasca trauma ringan dialami oleh $2 \%$ responden, sedangkan $19 \%$ tidak ada gejala. Gejala stres pasca trauma yang menonjol adalah perasaan jauh dan terpisah dari orang lain dan perasaan selalu waspada, hati-hati, dan waspada. Sementara itu, pemeriksaan lanjutan yang dilakukan terhadap 2.364 responden di 34 provinsi menyatakan, hasilnya tidak jauh berbeda dengan pemeriksaan sebelumnya. Sebanyak 69\% responden mengalami masalah psikologis. Sebanyak 68\% mengalami kecemasan, 67\% mengalami depresi, dan 77\% mengalami trauma psikologis. Sebanyak 49\% responden memikirkan kematian. Data tersebut menggambarkan bahwa gangguan jiwa akibat kecemasan, depresi, trauma akibat pandemi Covid-19 dirasakan masyarakat Indonesia saat ini

Masalah kesehatan mental seperti kecemasan, depresi, dan trauma akibat Covid-19 dirasakan sebagian besar masyarakat Indonesia. Beberapa faktor risiko utama adalah jarak sosial dan isolasi, resesi ekonomi, stres dan trauma pada masyarakat dan diskriminasi. Terhadap stigma tersebut, pemerintah meluncurkan bakti sosial untuk membantu menghadapi ancaman psikologis masyarakat akibat pandemi Covid-19 (Thakur \& Jain, 2020).

Peneliti mengambil survey data masyarakat di Desa Simangalam Kecamatan Kualuh Selatan Kabupaten Labuhan Batu Utara ada 756 orang sehingga saya tertarik untuk mengidentifikasi gambaran Stres Masyarakat terhadap Covid-19 di Desa Simangalam Kecamatan Kualuh Selatan Labuhan Batu Utara Daerah.

Tujuan dari penelitian ini adalah untuk mengetahui gambaran tingkat stres masyarakat terhadap penyakit Covid-19 di Desa Simangalam Kecamatan Labuhan Batu Utara Kabupaten Kualuh Selatan tahun 2021. Penelitian ini menggunakan desain penelitian deskriptif.

\section{METODE PENELITIAN}

Rancangan penelitian desskriptif, penelitian ini dilakukan di Desa Simangalam Kecamatan Kualuh Kabupaten Labuhan Batu Utara. Total sampel dalam penelitian ini adalah masyarakat desa simangalam kecamatan labuhan batu utara sebanyak 51 orang responden kriteria responden tidak dalam keadaaan sakit dan bersedia menjadi responden yang dengan teknik pengambilan sampel proportional sampling.

\section{HASIL DAN PEMBAHASAN}

Tabel 1. Distribusi Frekuensi Responden Tingkat Stress Masyarakat Terhadap Covid-19

\begin{tabular}{lll}
\hline Karakteristik & $F$ & $\%$ \\
\hline Umur & & \\
$30-40$ & 26 & 51,0 \\
$41-50$ & 15 & 29,4 \\
$>50$ & 10 & 35,3 \\
\hline Total & 51 & 100 \\
\hline Jenis & & \\
kelamin & 25 & 49,0 \\
Laki-laki & 26 & 51,0 \\
Perempuan & & \\
\hline
\end{tabular}

Jurnal Impresi Indonesia (JII) Vol. 1, No. 2, Februari 2022 


\begin{tabular}{llll}
\hline Total & 51 & 100 \\
\cline { 2 - 3 } Pendidikan & & \\
SMA & 35 & 68,6 \\
DII & 6 & 11,8 \\
S1 & 10 & 19,6 \\
\cline { 2 - 3 } Total & 51 & 100 \\
\cline { 2 - 3 } Pekerjaan & & \\
Petani & 15 & 29,4 \\
Buruh kebun & 16 & 31,4 \\
Petani & 5 & 9,8 \\
PNS & 11 & 21,6 \\
IRT & 4 & 7,8 \\
\hline Total & 51 & 100 \\
\hline Agama & 18 & 35,3 \\
Katolik & 18 & 43,1 \\
Protestan & 22 & 21,6 \\
Islam & 11 & 100 \\
\hline Total & 51 & . \\
\hline
\end{tabular}

Berdasarkan kategori umur responden sebagian besar berusia 30-40 tahun yaitu 26 orang $(51,0 \%)$ Berdasarkan jenis kelamin, sebagian besar adalah perempuan, 26 orang (51,0\%). Berdasarkan pendidikan terakhir responden sebagian besar tamatan SMA sebanyak 35 orang (68,6\%). Berdasarkan pekerjaan sebagian besar pekerja kebun yaitu sebanyak 16 orang $(31,4 \%)$. Berdasarkan agama responden sebagian besar beragama Protestan yaitu 22 orang $(43,1 \%)$.

Berdasarkan hasil penelitian yang dilakukan peneliti di Desa Simangalam, Kecamatan Kualuh Selatan, Kabupaten Labuhan Batu Utara. Gambaran tingkat stres masyarakat terhadap Covid-19 di Desa Simangalam Kecamatan Kualuh Selatan Kabupaten Labuhan Batu Utara tahun 2021 dengan tingkat stres ringan sebanyak 45 orang $(88,2 \%)$ dan tingkat stres sedang sebanyak 6 orang $(11,8 \%)$. Dapat disimpulkan bahwa tingkat stres masyarakat terhadap penyakit Covid-19 di Desa Simangalam Kecamatan Kualuh Selatan Kabupaten Labuhan Batu Utara berada pada kategori ringan.

\section{Tabel 2. Distribusi Frekuensi Tingkat Stres Responden Terhadap Gambaran Tingkat Stress Masyarakat Terhadap Covid-19

\begin{tabular}{lll}
\hline Kategori & $\boldsymbol{F}$ & $\mathbf{\%}$ \\
\hline Normal & $\mathrm{O}$ & $\mathbf{0}$ \\
Ringan & 45 & 88,2 \\
Sedang & 6 & 11,8 \\
Berat & $\mathrm{O}$ & $\mathrm{O}$ \\
\hline Total & 51 & 100 \\
\hline
\end{tabular}

Berdasarkan tabel 2 di atas diketahui bahwa jumlah responden dengan tingkat stres ringan adalah 45 orang $(88,2 \%)$ dan 6 orang dengan tingkat stres sedang $(11,8 \%)$.

Berdasarkan hasil penelitian, tingkat stres masyarakat terhadap penyakit Covid-19 di Desa Simangalam, Kecamatan Kualuh Selatan, Kabupaten Labuhan Batu Utara, dari 51 responden penelitian, 45 orang $(88,2 \%)$ memiliki tingkat stres ringan dan 6 orang $(11,8 \%)$ memiliki tingkat stres sedang. Dari data yang diperoleh, gambaran tingkat stres masyarakat terhadap COVID-19 di Desa Simangalam Kecamatan Kualuh Selatan Kabupaten Labuhan Batu Utara tingkat stres dalam kategori ringan. Penelitian ini di dukung oleh (Suhamdani, Wiguna, Hardiansah, Husen, \& Apriani, 2020) kecemasan atau gejala Stres sangat umum terjadi di kalangan tenaga kesehatan khususnya perawat yang sedang menangani pasien dalam menghadapi pandemi Covid-19 (Pappa et al., 2020). Sumber stres utama bagi perawat saat menghadapi pandemi COVID-19 adalah ketika mereka sadar akan rasa takut tertular atau menulari orang lain, termasuk kurangnya alat pelindung diri (Mo et al., 2020). 
Hasil penelitian ini didominasi oleh tingkat stres rendah sebanyak 30 orang atau $57 \%$ perawat yang memiliki gejala stres ringan, sedangkan perawat yang memiliki tingkat stres tinggi sebanyak 23 orang atau 43\%.

Menurut (Atkinson, Lilley, \& Urwin, 2013), stres terjadi ketika ada suatu peristiwa yang kemudian akan menjadi sesuatu yang dianggap berbahaya bagi individu, yang darinya individu akan bereaksi, baik secara fisik maupun psikologis. Lebih lanjut, Lazarus (2013) dalam (Nursalim, 2013) mengatakan bahwa stres adalah suatu peristiwa fisik atau psikologis yang dirasakan sebagai ancaman potensial terhadap gangguan fisik dan psikologis. Ahli lain, Kartono dan Gulo (2009) dalam (Triantoro \& Nofrans, 2009) menambahkan bahwa pengertian stres adalah suatu kondisi ketegangan fisik dan psikologis yang disebabkan oleh persepsi ketakutan dan ancaman.

(Triantoro \& Nofrans, 2009) memberikan pernyataan berikut tentang stres melalui pendekatan pertama, dilihat dari respon stres, pengertian stres terkait dengan tekanan yang membuat seseorang tidak berdaya dan berdampak negatif, misalnya pusing, lekas marah, sedih. sulit berkonsentrasi, sulit tidur. Kedua, stres berkaitan dengan sistem stresor (sumber stres), dalam hal ini stres digambarkan sebagai suatu kekuatan yang menimbulkan tekanan dalam diri seseorang. Helmi dalam (Triantoro \& Nofrans, 2009) menyatakan bahwa stres muncul ketika tekanan yang dihadapi melebihi batas optimum setiap individu. Selanjutnya, pendekatan ketiga adalah pendekatan interaksionis yang berfokus pada definisi stres dengan transaksi antara tekanan eksternal dan karakteristik individu yang menentukan apakah tekanan tersebut menyebabkan stres atau tidak.

Hasil penelitian yang dilakukan peneliti tentang gambaran tingkat stres masyarakat terhadap Covid-19 di Desa Simangalam Kecamatan Kualuh Selatan Kabupaten Labuhan Batu Utara, dari 51 responden penelitian, 45 orang $(88,2 \%)$ memiliki tingkat stres ringan. dan 6 orang $(11,8 \%)$ tingkat stres sedang. Hasil penelitian ini sejalan dengan penelitian yang dilakukan oleh Eka Raisa dkk, (2014) berdasarkan hasil penelitian dapat diketahui bahwa pada kelompok yang mengatakan tidak takut dengan perasaannya sendiri tentang persalinan mengalami tingkat stres 1 orang (9,1\%), tingkat stres sedang 2 orang $(18,2 \%)$, dan tingkat stres ringan 8 orang $(72,7 \%)$. Pada kelompok yang mengaku takut dengan perasaannya sendiri tentang persalinan, 6 orang mengalami tingkat stres berat (19,4\%), 12 orang mengalami stres sedang $(38,7 \%)$, dan 13 orang mengalami tingkat stres ringan $(41,9 \%)$. Pada kelompok yang menyatakan sangat takut dengan perasaannya sendiri tentang persalinan, mengalami tingkat stres ringan o orang (o\%), kecemasan tingkat sedang sebanyak o orang (o\%), dan tingkat stres berat. sebanyak 1 orang (100\%).

\section{KESIMPULAN}

Berdasarkan hasil penelitian ini dengan sampel 51 responden tentang gambaran tingkat stres masyarakat terhadap covid-19 di desa simangalam kecamatan kualuh selatan kabupaten labuhan batu utara tahun 2021:

1. Tingkat stres masyarakat terhadap penyakit Covid-19 di Desa Simangalam, Kecamatan Kualuh Selatan, Kabupaten Labuhan Batu Utara tahun 2021, tingkat stres masyarakat tertinggi adalah tingkat stres ringan sebanyak 26 orang $(88,2 \%)$

2. Tingkat stres masyarakat terhadap penyakit Covid-19 di desa simangalam kecamatan kualuh selatan kabupaten labuhan batu utara tahun 2021 tingkat stres masyarakat terendah adalah tingkat stres sedang sebanyak 6 orang $(11,8 \%)$

3. Tingkat stres masyarakat tertinggi terhadap penyakit Covid-19, responden menjawab tingkat stres ringan sebanyak 26 orang $(88,2 \%)$ dan terendah menjawab tingkat stres sedang sebanyak 6 orang $(11,2 \%)$

\section{BIBLIOGRAFI}

Atkinson, Nicky J., Lilley, Catherine J., \& Urwin, Peter E. (2013). Identification of genes involved in the response of Arabidopsis to simultaneous biotic and abiotic stresses. Plant Physiology, 162(4), 2028-2041. Google Scholar 
Handayani, Trisni, Ayubi, Dian, \& Anshari, Dien. (2020). Literasi Kesehatan Mental Orang Dewasa dan Penggunaan Pelayanan Kesehatan Mental. Perilaku Dan Promosi Kesehatan: Indonesian Journal of Health Promotion and Behavior, 2(1), 9-17. Google $\underline{\text { Scholar }}$

Huang, Yeen, \& Zhao, Ning. (2020). Generalized anxiety disorder, depressive symptoms and sleep quality during COVID-19 outbreak in China: a web-based cross-sectional survey. Psychiatry Research, 288, 112954. Google Scholar

Mo, Yuanyuan, Deng, Lan, Zhang, Liyan, Lang, Qiuyan, Liao, Chunyan, Wang, Nannan, Qin, Mingqin, \& Huang, Huiqiao. (2020). Work stress among Chinese nurses to support Wuhan in fighting against COVID-19 epidemic. Journal of Nursing Management, 28(5), 1002-1009. Google Scholar

Nursalim, Mochamad. (2013). Strategi dan intervensi konseling. Jakarta: Akademia Permata. Google Scholar

Pappa, Sofia, Ntella, Vasiliki, Giannakas, Timoleon, Giannakoulis, Vassilis G., Papoutsi, Eleni, \& Katsaounou, Paraskevi. (2020). Prevalence of depression, anxiety, and insomnia among healthcare workers during the COVID-19 pandemic: A systematic review and meta-analysis. Brain, Behavior, and Immunity, 88, 901-907. Google $\underline{\text { Scholar }}$

Suhamdani, Haris, Wiguna, Reza Indra, Hardiansah, Yayan, Husen, Lalu Muhammad Sadam, \& Apriani, Lia Arian. (2020). Hubungan Efikasi Diri dengan Tingkat Kecemasan Perawat pada Masa Pandemi Covid-19 di Provinsi Nusa Tenggara Barat: Relationship between Self Effication and Nurse Anxiety During The Covid-19 Pandemic in West Nusa Tenggara Province. Bali Medika Jurnal, 7(2), 215-223. Google Scholar

Sulis, Winurini. (2020). Permasalahan Kesehatan Mental Akibat Pandemi Covid-19. Diakses. Google Scholar

Thakur, Vikram, \& Jain, Anu. (2020). COVID 2019-suicides: A global psychological pandemic. Brain, Behavior, and Immunity, 88, 952. Google Scholar

Triantoro, Safaria, \& Nofrans, Eka. (2009). Manajemen Emosi. Jakarta: PT Bumi Aksara. Google Scholar

Vahia, Ipsit V, Blazer, Dan G., Smith, Gwenn S., Karp, Jordan F., Steffens, David C., Forester, Brent P., Tampi, Rajesh, Agronin, Marc, Jeste, Dilip V, \& Reynolds, Charles F. (2020). COVID-19, mental health and aging: a need for new knowledge to bridge science and service. The American Journal of Geriatric Psychiatry, 28(7), 695-697. Google Scholar

Xiang, Yu Tao, Yang, Yuan, Li, Wen, Zhang, Ling, Zhang, Qinge, Cheung, Teris, \& Ng, Chee H. (2020). Timely mental health care for the 2019 novel coronavirus outbreak is urgently needed. The Lancet Psychiatry, 7(3), 228-229. Google Scholar 